\title{
Phenotypic and genomic evidence for the revision of Pseudomonas corrugata and proposal of Pseudomonas mediterranea sp. nov.
}

\footnotetext{
1 DISTEF, Patologia Vegetale, Università di Catania, Via Valdisavoia 5, 95123 Catania, Italy

2 UMR de Pathologie Végétale INRA-INHUniversité, Beaucouzé, France

${ }^{3}$ Laboratoire d'Ecologie Microbienne de la Rhizosphère, UMR 163 CNRS-CEA, CEA Cadarache, Saint-Paul-lez-Durance, France

${ }^{4}$ Université de Paris $\mathrm{VI} / \mathrm{CNRS}$, Station Zoologique, Villefranchesur-Mer, France
}

\author{
Vittoria Catara, ${ }^{1}$ Laurent Sutra, ${ }^{2}$ Audrey Morineau, ${ }^{2}$ Wafa Achouak, ${ }^{3}$ \\ Richard Christen ${ }^{4}$ and Louis Gardan ${ }^{2}$ \\ Author for correspondence: Vittoria Catara. Tel: + 39095 234412. Fax: + 39095350043 . \\ e-mail: vittoria@mbox.fagr.unict.it
}

\begin{abstract}
To re-examine the taxonomic status of Pseudomonas corrugata, 27 strains of this species were studied using a polyphasic approach. Numerical analysis of phenotypic data revealed two phena, A (including the $P$. corrugata type strain) and $B$, which could be clearly differentiated by the assimilation of mesotartrate, 2-ketogluconate and histamine. The mean DNA reassociation values with labelled DNA of $P$. corrugata type strain CFBP $2431^{\top}$ (phenon A) and strain CFBP $5447^{\top}$ (phenon B) were high for strains belonging to the same phenon (96.9 and 98.5\%, respectively), whereas the DNA relatedness between the two phena was assessed as being close to $70 \%$, which represents the value that is accepted for the definition of a bacterial species. Phena A and B were also differentiated by means of DNA profiles generated by heteroduplex mobility assay of PCR products of 165 rDNA hypervariable region 2, Haelll restriction of the amplified internal transcribed spacer, REP- and BOX-PCR profiles, and by PCR with two pairs of specific primers. A comparison of the 16S rRNA sequences of strains CFBP $5447^{\top}$ and CFBP 5458 from phenon B with the available sequences of Pseudomonas species showed that these strains formed a cluster distinct from the $P$. corrugata type strain. Thus, a new species, Pseudomonas mediterranea, is proposed for strains of phenon $B$. The type strain is strain CFBP $5447^{\top}$ ( = ICMP 14184'); its G+C content is $60 \cdot 2 \mathrm{~mol} \%$.
\end{abstract}

Keywords: Pseudomonas corrugata, Pseudomonas mediterranea sp. nov., polyphasic taxonomy, phenotypic clustering, genomic variability

\section{INTRODUCTION}

The genus Pseudomonas has been thoroughly revised over the last 20 years (Kersters et al., 1996). At present, the genus Pseudomonas sensu stricto includes species within rRNA similarity group I (Palleroni, 1984) or the fluorescens rRNA branch (De Vos et al., 1985) and belongs to the $\gamma$-subclass of the Proteobacteria

Published online ahead of print on 14 March 2002 as DOI 10.1099/ ijs.0.02174-0.

Abbreviations: HMA, heteroduplex mobility assay; ITS, internal transcribed spacer; rep-PCR, repeat sequence primed PCR; BOX-PCR, PCR targeting BOXA subunit of Streptococcus pneumoniae BOX element; REP$P C R$, repetitive extragenic palindromic sequence PCR.

The GenBank accession numbers for the $16 \mathrm{~S}$ rDNA sequences of strains CFBP $5447^{\top}$ and CFBP 5458 are AF386080 and AF386081, respectively.
(Kersters et al., 1996). This genus refers to essentially fluorescent species but also includes some nonfluorescent species, of which Pseudomonas corrugata is an example. Pseudomonas corrugata Roberts and Scarlett 1981 emend. Sutra et al. (1997) was first described as being responsible for tomato pith necrosis (Scarlett et al., 1978). It has also been reported to cause a similar disease on chrysanthemum (Fiori, 1992), pepper (Lopez et al., 1994) and geranium (Magyarosy \& Buchanan, 1995). Nevertheless, P. corrugata is a ubiquitous bacterium and has been isolated from a variety of sources: from soil and from the rhizospheres of different plant species (Lukezic, 1979; Scortichini, 1989; Ryder \& Borrett, 1991; Paulitz et al., 1992; Achouak et al., 2000); from rice grains (Van Outryve et al., 1992); from mungbean sprouts (Bennik et al., 1998); and from broccoli heads (Padaga et al., 
2000). P. corrugata does not produce fluorescent pigments, and accumulates medium-chain-length poly(hydroxyalkanoates) (Kessler \& Palleroni, 2000; Solaiman et al., 2000). Chemotaxonomic studies based on analyses of quinone and fatty acids (Stead, 1992) and on SDS-PAGE of whole-cell proteins (Vancanneyt et al., 1996) have placed $P$. corrugata among the fluorescent pseudomonads. Moreover, on the basis of 16S rDNA sequence analysis, Anzai et al. (2000) placed $P$. corrugata in the Pseudomonas fluorescens group. The emended description of $P$. corrugata based on a polyphasic study indicated that this species appeared to be closely related to three unnamed Pseudomonas genomospecies - FP1, FP2 and FP3 (FP, fluorescent pseudomonads) - associated with tomato pith necrosis (Sutra et al., 1997).

Evidence of the variability of $P$. corrugata has been provided in different studies in which phenotypic, chemotaxonomic and serological properties and DNA/DNA hybridization data were compared (Siverio et al., 1993, 1996; Catara et al., 1997; Sutra et al., 1997). Three phenotypic groups (1, 2 and 3) were identified among $P$. corrugata strains isolated from Sicily, Italy (Catara et al., 1997). Sutra et al. (1997) observed that the phenon, which included 87 P. corrugata strains from all over the world, was divided into two subphena, 1a and $1 \mathrm{~b}$; the mean percentages of DNA reassociation with the $P$. corrugata type strain were $91 \%$ for strains of subphenon $1 \mathrm{a}$ and $75 \%$ for strains of subphenon $1 \mathrm{~b}$, providing evidence of genomic variability among $P$. corrugata strains. Genomic variability has been also observed in $P$. corrugata by means of enterobacterial repetitive intergenic consensus-PCR and amplified rDNA restriction analysis (Achouak et al., 2000) and by random amplified polymorphic DNA (Catara et al., 2000). A collection of $P$. corrugata strains analysed by multiplex PCR with two pairs of specific primers produced one of the two possible specific bands, and were consequently assigned to two groups, I and II, respectively (Catara et al., 2000). In this study, $P$. corrugata strains from subphena 1a (three strains) and $1 \mathrm{~b}$ (three strains) of Sutra et al. (1997) showed an amplification band of type I and type II, respectively (Catara et al., 2000).

In the present study, 27 strains representative of the various groups previously observed within $P$. corrugata (Catara et al., 1997; Sutra et al., 1997) were investigated using numerical analysis of phenotypic tests, DNA-DNA hybridization, DNA fingerprinting techniques and $16 \mathrm{~S}$ rDNA sequence analysis. The outcome of this study is the revision of the taxonomic status of $P$. corrugata and the description of a new Pseudomonas species for which the name of Pseudomonas mediterranea is proposed.

\section{METHODS}

Bacterial strains. Twenty-seven $P$. corrugata strains were chosen on the basis of phenotypic data previously obtained by Sutra et al. (1997) and Catara et al. (1997) (Table 1). They are designated under their CFBP (Collection Française des Bactéries Phytopathogènes, Angers, France) number. Type strains of six major fluorescent oxidase-positive Pseudomonas species were also included in this study: Pseudomonas aeruginosa CFBP $2466^{\mathrm{T}}$, P. fluorescens CFBP $2102^{\mathrm{T}}$, Pseudomonas putida biovar A CFBP $2066^{\mathrm{T}}$, Pseudomonas marginalis pathovar marginalis CFBP $1387^{\mathrm{T}}$, Pseudomonas fuscovaginae CFBP $2065^{\mathrm{T}}$ and Pseudomonas cichorii CFBP $2101^{\mathrm{T}}$. All strains were routinely cultivated on King's B medium.

Numerical analysis of phenotypic data. Twenty conventional biochemical tests were performed as described by Sutra et al. (1997). The assimilation of 99 organic substrates was tested using Biotype 100 strips (bioMérieux) as recommended by the manufacturer. Results were read visually after $4 \mathrm{~d}$ incubation at $26^{\circ} \mathrm{C}$. The results of these 119 tests were used for a numerical analysis performed as previously described (Sutra et al., 1997). A diagnostic coefficient capacity value was determined for each test (Descamps \& Véron, 1981).

DNA-DNA hybridization and DNA base composition. Extraction of DNA and DNA-DNA hybridization experiments were performed as reported by Sutra et al. (1997). Native DNAs of $P$. corrugata type strain CFBP $2431^{\mathrm{T}}$ and of strain CFBP $5447^{\mathrm{T}}$ were labelled in vitro by random priming (Feinberg \& Vogelstein, 1983) using a Megaprime DNAlabelling system (RPN 1604; Amersham International). DNA-DNA hybridization experiments were repeated two or three times. The $\mathrm{G}+\mathrm{C}$ content of strain CFBP $5447^{\mathrm{T}}$ was determined by means of the thermal denaturation temperature (Marmur \& Doty, 1962), and were calculated using the equation of Owen \& Lapage (1976).

PCR of the ribosomal operon. Three regions, HV1, HV2 and $\mathrm{HV} 3$, of the $16 \mathrm{~S}$ rDNA of $P$. corrugata strains and of $P$. aeruginosa CFBP $2466^{\mathrm{T}}$, which contained the hypervariable regions $h v 1, h v 2$ and $h v 3$, respectively, as defined by Moore et al. (1996), were amplified by PCR. The primers were defined from the $16 \mathrm{~S}$ rDNA sequence of the $P$. aeruginosa type strain (Moore et al., 1996). The following primer pairs were used: fD1 (5'-AGAGTTTGATCATGGCTCAG-3') and rSSU2 (5'-GTAAGAGTCTGGACCGTGTC-3') for HV1; fSSU1 (5'-AGACACGGTCCAGACTCCTACG-3') and rSSU1 (5'-ACGCATTTCACCGCTACACAGG-3') for HV2; and fSSU4 (5'-AGTCCACGCCGTAAACGATGTC-3') and rSSU3 (5'-TCACCGGCAGCTTCCTTAGAGT-3') for HV3. The internal transcribed spacer (ITS) between 16S rRNA and 23S rRNA genes was amplified using primers D21 and D22 (Manceau \& Horvais, 1997). All PCRs were performed in a $50 \mu \mathrm{l}$ reaction volume. A $2 \mu \mathrm{l}$ volume of freeze-and-sow bacterial cells $\left(\mathrm{OD}_{600}=0 \cdot 5\right)$ was added to $48 \mu \mathrm{l} \mathrm{PCR}$ mixture $[75 \mathrm{mM}$ Tris $/ \mathrm{HCl}, \mathrm{pH} 9.0$ (at $\left.25^{\circ} \mathrm{C}\right), 20 \mathrm{mM}\left(\mathrm{NH}_{4}\right)_{2} \mathrm{SO}_{4}, 0.01 \%$ Tween $20,2.5 \mathrm{mM}$ $\mathrm{MgCl}_{2}, 0 \cdot 125 \mathrm{mM}$ (each) dATP, dCTP, dGTP and dTTP (Eurogentec), 25 pmol each primer, and $1 \mathrm{U}$ thermostable DNA polymerase (Goldstar Red; Eurogentec)]. PCRs were performed in a PTC 100 (MJ Research) thermocycler with the following steps: an initial denaturation step at $94{ }^{\circ} \mathrm{C}$ for $3 \mathrm{~min} ; 35$ cycles of $95^{\circ} \mathrm{C}$ for $1 \mathrm{~min}, 55^{\circ} \mathrm{C}$ for $1 \mathrm{~min}$ and $72{ }^{\circ} \mathrm{C}$ for $2 \mathrm{~min}$; and a final extension step at $72{ }^{\circ} \mathrm{C}$ for $15 \mathrm{~min}$. PCR products were separated in $1.5 \%(\mathrm{w} / \mathrm{v})$ agarose gel (Eurogentec) in TAE buffer (Sambrook et al., 1989).

Heteroduplex mobility assay (HMA). For each amplified HV region of the $16 \mathrm{~S}$ rDNA, heteroduplexes were formed by combining $9 \mu \mathrm{l}$ of the PCR product of each strain of $P$. corrugata, $9 \mu \mathrm{l}$ of the PCR product of the corresponding region of $P$. aeruginosa $\mathrm{CFBP} 2466^{\mathrm{T}}$ and $2 \mu$ annealing buffer (1 M NaCl, $100 \mathrm{mM}$ Tris, $20 \mathrm{mM}$ EDTA). DNA was 
Table 1. Origin of $P$. corrugata strains used in this study

All strains were isolated from sites of pith necrosis on tomato, except strain CFBP 10148 (from pepper) and strain CFBP 5459 (from soil in which infected tomato plants were grown). CFBP, Collection Française des Bactéries Phytopathogènes, Angers, France; ICMP, International Collection of Microorganisms from Plants, Auckland, New Zealand.

\begin{tabular}{|cll|}
\hline Original phenon & \multicolumn{1}{c|}{ CFBP strain no. (other designation) } & Geographic origin \\
\hline $1 \mathrm{a}^{*}$ & $2431^{\mathrm{T}}$ (ICMP 5819) & England \\
& $10058($ ICMP 8893) & New Zealand \\
& $10146,10890,10900,10904,10950$ & Spain \\
& 10938 & Switzerland \\
& 10532 & France \\
& $10148,10894,10961$ & Spain \\
$1 \mathrm{~b}^{*}$ & 10558 & France \\
& $5444(8.1), 5434(1.4), 5447(9.1), 5458(3 \mathrm{C})$ & Italy \\
$1 \dagger$ & $5436(2.1), 5438(3.1), 5442(7.6)$, & Italy \\
$2 \dagger$ & $5449(10.3), 5451(10.8), 5454(\mathrm{~A} 1)$, & \\
& $5456(\mathrm{D} 1), 5459(4.3 \mathrm{t})$ & Spain \\
\hline
\end{tabular}

* Phenon described by Sutra et al. (1997).

$\dagger$ Phenon described by Catara et al. (1997).

denaturated at $95{ }^{\circ} \mathrm{C}$ for 5 min, annealed by rapid cooling in ice and maintained in ice for $1.5 \mathrm{~h}$ before analysis. The DNA fragments were separated in $5 \%(\mathrm{w} / \mathrm{v})$ polyacrylamide gels in TBE buffer $(0.044 \mathrm{M}$ Tris, $0.044 \mathrm{M}$ boric acid, $0.001 \mathrm{M}$ EDTA) at $250 \mathrm{~V}$ for $2 \mathrm{~h}$ (Delwart et al., 1993). Gels were stained with ethidium bromide and examined under UV light.

Restriction of ITS. Amplified DNA from the ITS was restricted with two high-frequency cutting enzymes, HaeIII and Hinf I (Eurogentec). A $10 \mu$ l volume of PCR product was used and digestion performed with $10 \mathrm{U}$ enzyme per reaction as recommended by the manufacturer. Restricted DNA was analysed by agarose gel electrophoresis as described above.

REP- and BOX-PCR. Strains were analysed by REP-PCR and BOX-PCR (Versalovic et al., 1994). PCR conditions were like those described by de Bruijn (1992) and Louws et al. (1994). Cell suspensions in sterile water $\left(10^{9}\right.$ c.f.u. $\left.\mathrm{ml}^{-1}\right)$, from $24 \mathrm{~h}$ bacterial cultures grown on nutrient glucose agar, were used as templates. Amplification was performed on the Gene Amp System 9700 (PE Applied Biosystems) using $25 \mu 1$ reaction volumes. PCR products were separated by $1.5 \%(\mathrm{w} / \mathrm{v})$ agarose gel electrophoresis in TAE buffer (Sambrook et al., 1989) at $5 \mathrm{~V} \mathrm{~cm}^{-1}$ over $5 \mathrm{~h}$. A distance matrix based on bands was calculated using the Jaccard coefficient, and a dendrogram was constructed with the unweighted pair group arithmetic average-linkage algorithm method using the NEIGHBOR program of the PHYLIP package (version 3.5c) (J. Felsenstein, Department of Genetics, University of Washington, Seattle, USA). Three analyses were performed for REP bands alone, BOX bands alone and REP and BOX bands together, respectively.

$16 \mathrm{~S}$ rDNA sequencing and phylogenetic analyses. The $16 \mathrm{~S}$ rDNA genes of strains CFBP $5447^{\mathrm{T}}$ and CFBP 5458 were amplified as described by Achouak et al. (1999). The PCR products were purified using the QIAquick PCR purification kit (Qiagen), and then subjected to direct sequencing using the ABI PRISM Dye Terminator Cycle Sequencing Ready
Reaction Kit (Applied Biosystems) according to the instructions of the manufacturer. DNA sequencing was performed using the previously described primers (Achouak et al., 1999). The 16S rDNA sequences were automatically, and then manually, aligned with reference to a database of 35000 already aligned bacterial $16 \mathrm{~S}$ rDNA sequences. They were then blasted against the current content of the EMBL database (Bacteria division) to check for the presence of newly submitted related sequences. Phylogenetic trees were constructed according to three different methods. BioNJ was performed according to Gascuel (1997), and maximumlikelihood and maximum-parsimony data were obtained from PHYLIP (Phylogeny Inference Package, version 3.573c, distributed by J. Felsenstein, Department of Genetics, UW, Seattle, WA, USA). For the bioNJ analysis, a matrix distance was calculated according to the Kimura twoparameter correction. Bootstraps were done using 500 replications, bioNJ and Kimura two-parameter corrections. The domains used to construct phylogenetic trees were regions of $16 \mathrm{~S}$ rDNA sequences available for all sequences and excluding positions likely to show homoplasy.

PCR amplification with $P$. corrugata-specific primers. A PCR was performed with type I primers PC5/1 and PC5/2 and type II primers PC1/1 and PC1/2 (Catara et al., 2000) on a Gene Amp PCR system 9700 (PE Applied Biosystems). The PCR programme used by Catara et al. (2000) was slightly modified as follows: one cycle of $5 \mathrm{~min}$ at $94^{\circ} \mathrm{C}$, followed by 30 cycles of $30 \mathrm{~s}$ at $94^{\circ} \mathrm{C}, 30 \mathrm{~s}$ at $62^{\circ} \mathrm{C}$ and $1 \mathrm{~min}$ at $72{ }^{\circ} \mathrm{C}$, with a final extension step of $5 \mathrm{~min}$ at $72^{\circ} \mathrm{C}$. Amplified products were resolved by electrophoresis at $5 \mathrm{~V}$ $\mathrm{cm}^{-1}$ in $1.5 \%(\mathrm{w} / \mathrm{v})$ agarose in TAE buffer (Sambrook et al., 1989).

Pathogenicity tests. Pathogenicity tests were performed in the greenhouse with a set of six strains of each of the two groups revealed by our phenotypic results (see Results and Discussion). Four-week-old plants of tomato (Lycopersicon esculentum cv. Camone, cv. Cronos, cv. Cemcara), pepper (Capsicum annuum cv. Lamuio), eggplant (Solanum melon- 


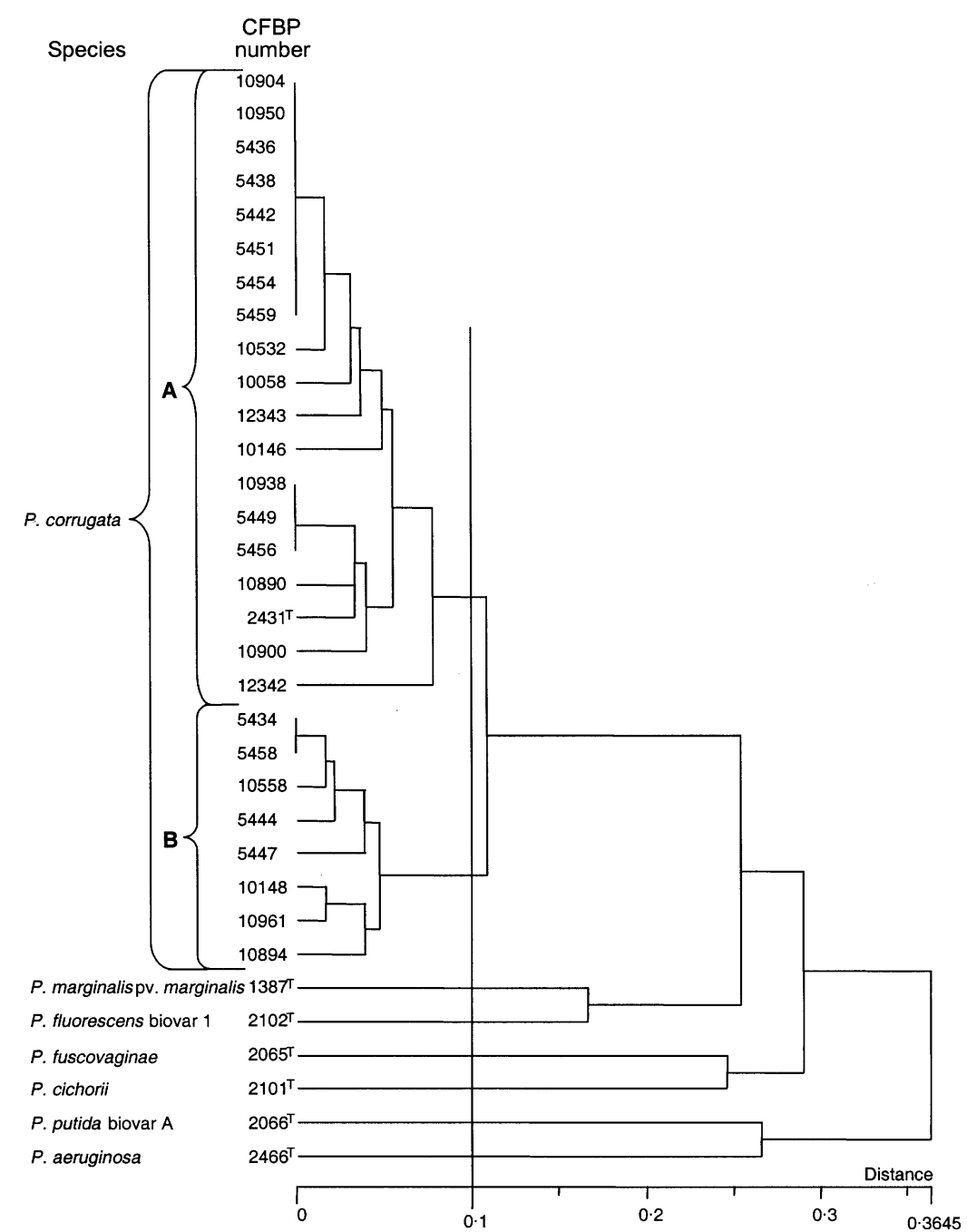

Fig. 1. Dendrogram of phenotypic distances between the 33 strains under study.

gena cv. Gitana), tobacco (Nicotiana tabacum cv. Burley), cucumber (Cucumis sativus cv. Frontera), watermelon (Citrullus lanatus cv. Crimson Sweet) and courgette (Cucurbita pepo cv. Romano) grown in trays were inoculated by injecting $50 \mu \mathrm{l}$ bacterial suspension into the stem at the axil of the first true leaf (five plants of each species or cultivar per bacterial strain). Control plants were inoculated with sterile distilled water. The inoculum consisted of bacterial suspensions in sterile distilled water prepared from a 24-hold culture and were adjusted to a concentration of $10^{8}$ c.f.u. $\mathrm{ml}^{-1}$. After inoculation, plants were enclosed in polyethylene bags to maintain $100 \%$ relative humidity for 3 days; the bags were then removed until the end of the experiment. Plants were rated for symptoms after 14 days: the stem of each plant was cut longitudinally and the length of pith necrosis measured. Reisolation of bacteria from each plant species tested was performed on nutrient glucose agar.

\section{RESULTS AND DISCUSSION}

\section{Numerical taxonomy of phenotypic data}

The major biochemical characteristics of the P. corrugata strains used in this study were similar to those reported by Sutra et al. (1997). A dendrogram displaying distance relationships among the 33 strains under study is presented in Fig. 1. At the distance level of $0 \cdot 1$, two phena and six unclustered strains were observed. Phena A and B contained 19 and eight $P$. corrugata strains, respectively, the $P$. corrugata type strain CFBP $2431^{\mathrm{T}}$ being included in phenon A. Phena $\mathrm{A}$ and $\mathrm{B}$ and unclustered strains were clearly differentiated on the basis of phenotypic traits (Table 2). Strains of $P$. corrugata included in phenon B utilized meso-tartrate, 2-ketogluconate and histamine, whereas strains of $P$. corrugata belonging to phenon A did not. The phenon A defined in the present study corresponds to subphenon 1a described by Sutra et al. (1997) and phena 2 and 3 described by Catara et al. (1997), whereas phenon B corresponds to subphenon $1 \mathrm{~b}$ reported by Sutra et al. (1997) and phenon 1 reported by Catara et al. (1997).

\section{DNA-DNA hybridization and DNA base composition}

The results obtained in this study, together with those previously reported by Sutra et al. (1997) using the same experimental conditions, are shown in Table 3. 
Table 2. Phenotypic characteristics that differentiate $P$. corrugata phena $A$ and $B$ and fluorescent Pseudomonas type strains

Type strains: 1, P. fluorescens CFBP $2102^{\mathrm{T}} ; 2$, P. fuscovaginae CFBP $2065^{\mathrm{T}} ; 3$, P. cichorii CFBP $2101^{\mathrm{T}} ; 4$, P. putida CFBP $2066^{\mathrm{T}} ; 5$, P. aeruginosa CFBP $2466^{\mathrm{T}} ; 6$, P. marginalis CFBP $1387^{\mathrm{T}}$. + , Positive; - , negative; $d$, variable (percentage of positive strains in parentheses).

\begin{tabular}{|c|c|c|c|c|c|c|c|c|}
\hline \multirow{2}{*}{$\begin{array}{l}\text { Characteristic } \\
\text { (diagnostic coefficient capacity) }\end{array}$} & \multicolumn{2}{|c|}{ Phenon (no. strains) } & \multicolumn{6}{|c|}{ Type strain } \\
\hline & A (19) & B (8) & 1 & 2 & 3 & 4 & 5 & 6 \\
\hline Fluorescence on Kings B medium $(0 \cdot 68)$ & - & - & + & + & + & + & + & + \\
\hline Nitrate reduction $(0.53)$ & + & + & - & - & - & + & + & - \\
\hline \multicolumn{9}{|l|}{ Assimilation of: } \\
\hline meso-Tartrate $(0.94)$ & - & + & + & + & + & + & - & - \\
\hline 2-Ketogluconate $(0 \cdot 94)$ & - & + & + & - & - & + & + & + \\
\hline Histamine $(0.88)$ & - & + & - & - & - & + & + & - \\
\hline DL-Lactate $(0.68)$ & + & + & - & - & - & - & - & - \\
\hline Mannitol (0.68) & + & + & - & - & - & - & - & - \\
\hline D-Xylose $(0.53)$ & + & + & + & - & - & - & - & + \\
\hline Sucrose $(0 \cdot 44)$ & + & + & - & - & - & - & + & - \\
\hline $\mathrm{D}(+)$-Trehalose $(0 \cdot 44)$ & + & + & + & + & - & - & - & + \\
\hline myo-Inositol $(0 \cdot 44)$ & + & + & + & - & + & - & - & + \\
\hline$N$-Acetylglucosamine $(0 \cdot 44)$ & + & + & + & - & - & - & + & + \\
\hline Benzoate $(0 \cdot 44)$ & - & - & + & - & - & + & + & - \\
\hline $\mathrm{D}(-)$-Tartrate $(0 \cdot 43)$ & d (63) & - & - & - & + & - & - & + \\
\hline
\end{tabular}

Table 3. Results of DNA-DNA hybridization experiments

Values in parentheses are $\Delta T_{\mathrm{m}}$ values $\left({ }^{\circ} \mathrm{C}\right) ; \mathrm{NT}$, not tested.

\begin{tabular}{|c|c|c|}
\hline \multirow[t]{2}{*}{ Unlabelled DNA from: } & \multicolumn{2}{|c|}{$\begin{array}{l}\text { Hybridization }(\%) \text { at } 70^{\circ} \mathrm{C} \\
\text { with labelled DNA from: }\end{array}$} \\
\hline & CFBP $2431^{\mathrm{T}}$ & CFBP $5447^{\mathrm{T}}$ \\
\hline \multicolumn{3}{|l|}{ Group A strains } \\
\hline CFBP $2431^{\mathrm{T}}$ & 100 & $68(4 \cdot 2)$ \\
\hline CFBP 10146 & 86 & NT \\
\hline CFBP 5449 & 102 & $67(3 \cdot 9)$ \\
\hline CFBP 5451 & 92 & NT \\
\hline CFBP 12342 & $91(0 \cdot 9)$ & NT \\
\hline CFBP 10058 & $106^{*}$ & NT \\
\hline CFBP 10900 & $98 *$ & NT \\
\hline CFBP 10904 & $98^{*}$ & NT \\
\hline Mean \pm SD & $96 \cdot 6 \pm 6 \cdot 6$ & $67 \pm 0 \cdot 7$ \\
\hline \multicolumn{3}{|l|}{ Group B strains } \\
\hline CFBP 5447 & $69(5 \cdot 6)$ & 100 \\
\hline CFBP 10894 & NT & 92 \\
\hline CFBP 5434 & $71(4 \cdot 7)$ & 94 \\
\hline CFBP 10558 & 71 & 103 \\
\hline CFBP 5458 & 71 & 101 \\
\hline CFBP 10148 & $69(3 \cdot 0)^{*}$ & NT \\
\hline CFBP 10558 & $66(3 \cdot 0)^{*}$ & 101 \\
\hline Mean $\pm S D$ & $69 \cdot 5 \pm 2$ & $98 \cdot 5 \pm 4 \cdot 3$ \\
\hline
\end{tabular}

* Values from Sutra et al. (1997).
The percentages of reassociation with $P$. corrugata type strain CFBP $2431^{\mathrm{T}}$ (phenon A) were over $86.0 \%$ for the strains of phenon $A$. They ranged from 66.0 to $71.0 \%$ for strains of phenon $\mathrm{B}$, with a mean $\Delta T_{\mathrm{m}}$ value of $4 \cdot 1{ }^{\circ} \mathrm{C}$ (range, $3 \cdot 0-5 \cdot 6^{\circ} \mathrm{C}$ ). The percentages of reassociation of strains CFBP $2431^{\mathrm{T}}$ and CFBP 5449 of phenon A with strain CFBP $5447^{\mathrm{T}}$ (phenon B) were 68.0 and $67.0 \%$, with $\Delta T_{\mathrm{m}}$ values of 4.2 and $3.9{ }^{\circ} \mathrm{C}$, respectively. The percentages of reassociation of strains of phenon B with $P$. corrugata strain CFBP $5447^{\mathrm{T}}$ (phenon B) were greater than $92 \cdot 0 \%$. The $\mathrm{G}+\mathrm{C}$ content of strain CFBP $5447^{\mathrm{T}}$ was $60 \cdot 2 \mathrm{~mol} \%$.

Thus the DNA-DNA hybridization percentages and $\Delta T_{\mathrm{m}}$ values observed for the two phena are close to the borderline applied to the bacterial species, i.e. approximately $70 \%$ of DNA-DNA hybridization and $\Delta T_{\mathrm{m}}$ values of $5{ }^{\circ} \mathrm{C}$ or less (Wayne et al., 1987). However, it has been pointed out that hybridization percentages of around $70 \%$ or $\Delta T_{\mathrm{m}}$ values of around $5{ }^{\circ} \mathrm{C}$ should be carefully interpreted (Grimont, 1988). The presence of phenotypic consistency among strains should be the deciding factor when attempting to delineate a species (Stackebrandt \& Goebel, 1994). Moreover, the $70 \%$ DNA relatedness values proposed by Wayne et al. (1987) should be considered as indicative rather than absolute, and an alternative phylogenetic species concept could delineate a species in a phylogenetic framework as determined by $16 \mathrm{~S}$ rRNA analyses (Vandamme et al., 1996). 


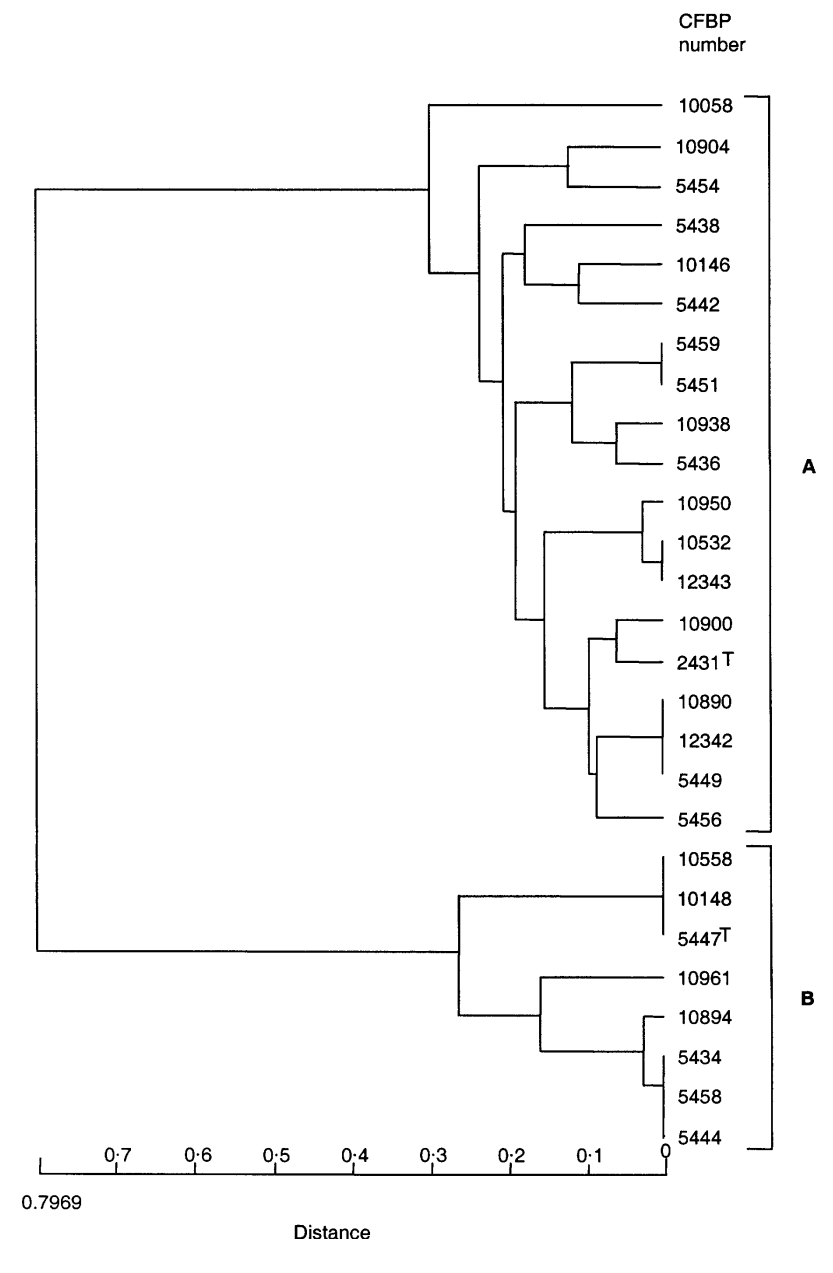

Fig. 2. Dendrogram of distances between the 27 strains of $P$. corrugata, based on total bands obtained by REP- and BOXPCR.

\section{REP- and BOX-PCR}

Complex fingerprints were generated: they consisted of 17-25 REP-PCR bands ranging from 0.5 to $7 \cdot 0 \mathrm{~kb}$ and 15-20 BOX-PCR bands ranging from 0.5 to
$5.0 \mathrm{~kb}$. Analysis of distances between strains, using the unweighted pair group arithmetic average-linkage algorithm method, indicated that both the REP and BOX primers were equally effective in delineating two genotypes (A and B). The dendrogram of distances shown in Fig. 2 is based on the analysis of REP and BOX-PCR bands together. The 19 strains of phenon A belong to genotype $\mathrm{A}$ and the eight strains of phenon $\mathrm{B}$ belong to genotype B. Only eight of the 49 REPPCR scored bands and five of the 34 BOX-PCR scored bands appeared to co-migrate among the two genotypes. REP- and BOX-PCR fingerprinting profiles were highly similar within each genotype. The numbers of fingerprinting patterns delineated by REP- and BOX-PCR were 15 and 9 for genotype A, and 4 and 3 for genotype B, respectively. The distinct or identical patterns could not be correlated with the geographic origins of isolates.

DNA fingerprints specific to Xanthomonas campestris and Pseudomonas syringae pathovars have been obtained using rep-PCR techniques (Louws et al., 1994), and a strong correlation has been observed between the grouping of Xanthomonas strains based on fingerprints generated by rep-PCR and the genomic species delineated by DNA-DNA hybridization (Rademaker et al., 1997, 2000; Vauterin et al., 2000). These results suggest that these techniques could complement DNA-DNA hybridizations in the definition of bacterial species.

\section{HMA and ITS restriction analysis}

Three DNA fragments of about $340 \mathrm{bp}$ (for HV1), $380 \mathrm{bp}$ (for HV2) and $370 \mathrm{bp}$ (for HV3) were amplified from the $16 \mathrm{~S}$ rDNA of all $P$. corrugata strains and of $P$. aeruginosa type strain CFBP $2466^{\mathrm{T}}$. These DNA fragments appeared as a single band in agarose gel electrophoresis (data not shown). HMA performed on PCR products from HV1 and HV3 regions of the $16 \mathrm{~S}$ rDNA generated a unique profile for all of the 27 $P$. corrugata strains tested, whereas HMA performed on PCR products from the HV2 region generated two different profiles (Fig. 3), which coincided with phena

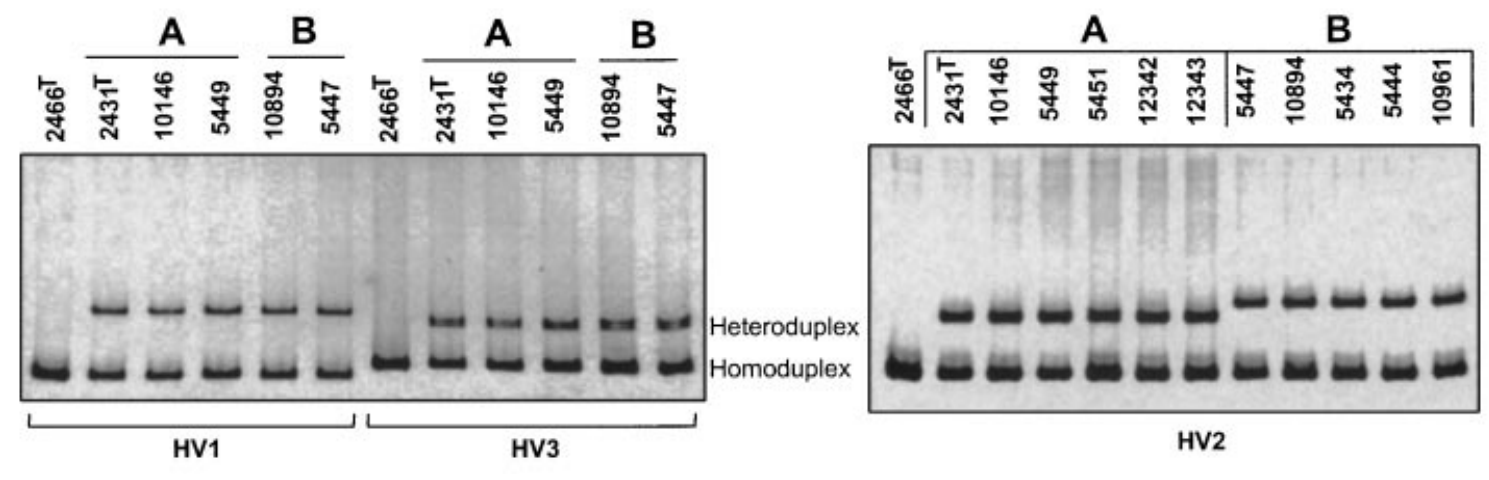

Fig. 3. Examples of HMA profiles of HV1 and HV3 (left) and HV2 (right) regions of the $16 \mathrm{~S}$ rRNA gene. 


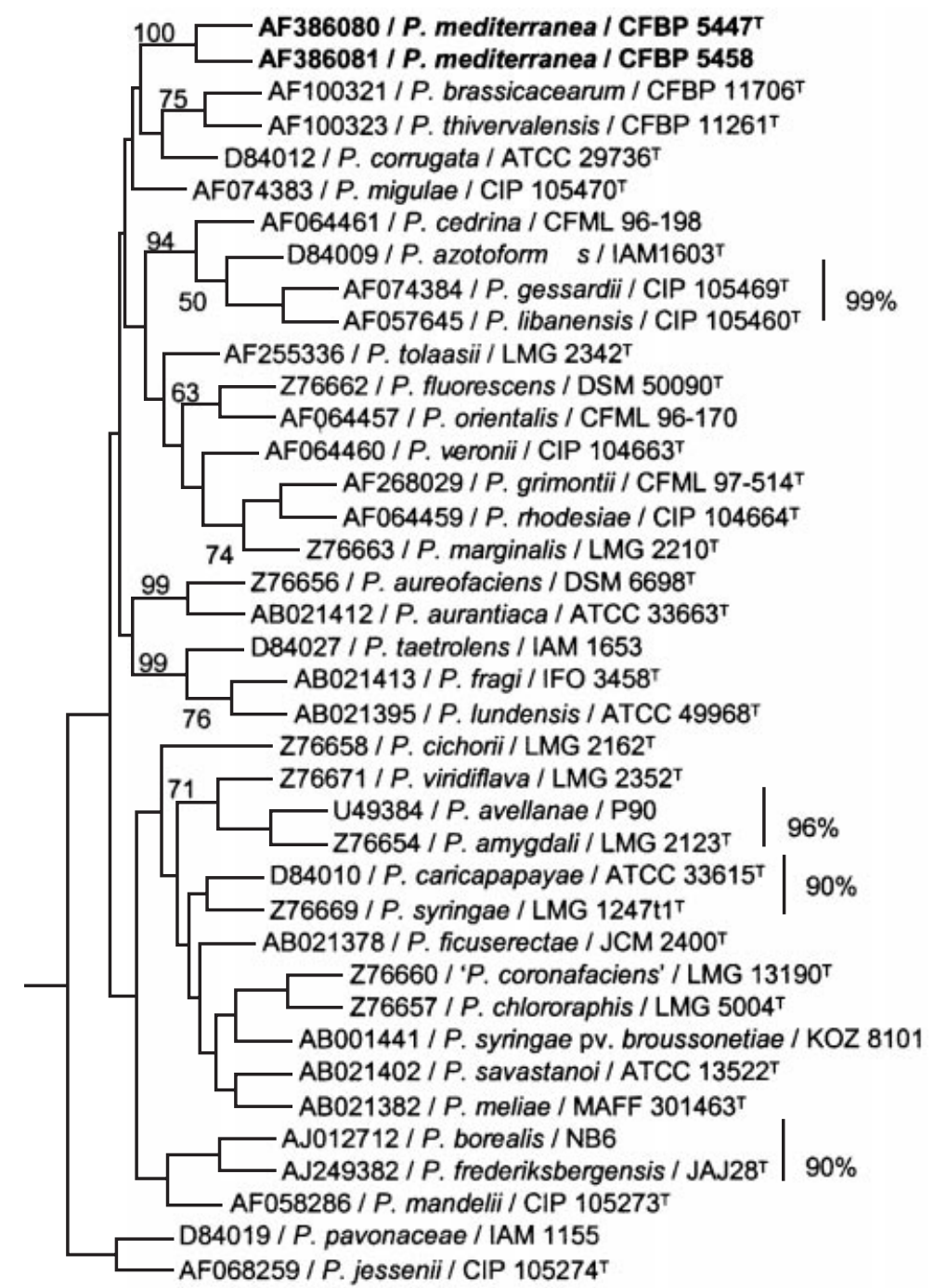

Fig. 4. Unrooted phylogenic tree obtained by $16 \mathrm{~S}$ rDNA sequence analysis. The topology shown is a restricted subset of a larger analysis including type species of the genus Pseudomonas. This tree was obtained using the bioNJ algorithm and 500 bootstrap replications with a Kimura two-parameter correction for the distances. Percentage bootstrap values are indicated only for branches that were also retrieved by maximum parsimony and maximum likelihood $(P<0.01)$; these branches should be considered as the only robust clusters identified by this analysis.
$\mathrm{A}$ and $\mathrm{B}$ described above and revealed sequence differences between them. HMA has been shown to be a powerful technique for screening sequence dissimilarities between annealed strands of DNA (Delwart et al., 1993), and has recently been applied to the assessment of the 16S rDNA similarity of bacterial isolates (Espejo et al., 1998). Approximately $44 \%$ of the total $16 \mathrm{~S}$ rRNA gene sequence variability observed for Pseudomonas species occurs in $6 \%$ of the gene sequence and is located in the three hypervariable regions $h v 1, h v 2$ and $h v 3$ (Moore et al., 1996). Amplification of the ITS yielded a DNA fragment of about $550 \mathrm{bp}$. Restriction of the amplified ITS with Hinf I generated the same restriction pattern for all of the $P$. corrugata strains tested. In contrast, two different patterns were generated for strains from phena A and B using HaeIII: pattern 1 consisted of two bands of about 330 and $220 \mathrm{bp}$, respectively, and pattern 2 consisted of a band of $227 \mathrm{bp}$ and supplementary bands of less than $100 \mathrm{bp}$. Because the ITS region is highly variable in sequence and size between bacterial organisms, its characterization made it possible to differentiate closely related taxa (Jensen et al., 1993).
For example, it has recently been used to differentiate $P$. syringae pathovars or groups of pathovars (Manceau \& Horvais, 1997) and Pseudomonas stutzeri genomovars (Guasp et al., 2000).

\section{$16 S$ rDNA sequence analysis}

The 16S rDNAs of strains CFBP $5447^{\mathrm{T}}$ and CFBP 5458 were shown to have $99 \cdot 2 \%$ similarity, and had 98.4 and $98.8 \%$ similarity with the $16 \mathrm{~S}$ rDNA of the $P$. corrugata type strain, respectively. The type strain of $P$. corrugata (phenon A) and strains CFBP $5447^{\mathrm{T}}$ and CFBP 5458 (phenon B) had identical sequences for the $h v 1$ and $h v 3$ regions: the $h v l$ sequence was identical to that of Pseudomonas chlororaphis, and the $h v 3$ sequence was identical to that of $P$. chlororaphis, P. marginalis, Pseudomonas aureofaciens and Pseudomonas tolaasii (Moore et al., 1996). In contrast, sequence differences were observed between $h v 2$ regions: the $h v 2$ region of the $P$. corrugata type strain was identical to that of $P$. fluorescens, whereas the $h v 2$ region of strains CFBP $5447^{\mathrm{T}}$ and CFBP 5458 was identical to that of $P$. marginalis (Moore et al., 1996). 
General large-scale phylogenetic analyses based on $16 \mathrm{~S}$ rDNA sequences showed that strains CFBP $5447^{\mathrm{T}}$ and CFBP 5458 are members of the $\gamma$-branch of the Proteobacteria, and that they clustered very robustly within the genus Pseudomonas sensu stricto (data not shown). The final analysis (almost the entire 16S rDNA sequences, corresponding to positions 65-1343 of the sequence of strain CFBP $5447^{\mathrm{T}}$ ) was effected only with sequences of the genus Pseudomonas (55 sequences, mostly of reference strains). The topology presented in Fig. 4, which represents a subset of the total analysis, is that of the bootstrap analysis, as it has been demonstrated that this topology is often better than that of a simple neighbour-joining analysis (Berry \& Gascuel, 1996). Strains CFBP $5447^{\mathrm{T}}$ and CFBP 5458 formed a very robust clade, as attested by a bootstrap value of $100 \%$. Because these strains could not be firmly included in a clade that comprised a single recognized species, our results suggest that these two strains can be equated to a single species. According to our analyses (Fig. 4), this species is included in a larger cluster that comprises the type strains of species such as $P$. corrugata, Pseudomonas brassicacearum and Pseudomonas thivervalensis.

\section{PCR amplification with $P$. corrugata specific primers}

The strains were assigned to group I or group II (sensu Catara et al., 2000) based on the sizes of the amplification products. Strains of phenon A were characterized by amplification of the $1100 \mathrm{bp}$ fragment (group I), and strains of phenon B were characterized by amplification of the $600 \mathrm{bp}$ fragment (group II). Thus, each pair of primers, type I and type II, is specific for the identification of strains of the two phena (A and B, respectively).

\section{Pathogenicity tests}

All strains tested were able to produce typical symptoms of pith necrosis in tomato, eggplant, pepper and tobacco plants. Brown water-soaked and/or dry pith with cavities which extended above and below the inoculation site was observed in almost all of the inoculated plants. A few of the plants showed a darkbrown hollow lesion around the inoculation site (about $0.5 \mathrm{~cm})$. The extent of the lesion in the pith was variable and ranged from 1 to $8 \mathrm{~cm}$ in tomato and from 3 to $11 \mathrm{~cm}$ in pepper. Most plants showed discoloration of the vascular system also extending 3-4 cm beyond the pith lesion. When inoculated into cucurbits, almost all $P$. corrugata strains induced yellow to orange discolorations of the pith. Only one strain (CFBP 5444) was clearly less virulent than the other strains, causing yellow discoloration at the inoculation sites on cucumber and watermelon and no symptoms on courgette. No symptoms were observed in control plants. Colonies with characteristics of $P$. corrugata were reisolated from the margins of pith lesions. Randomly selected colonies retrieved from isolation plates were positive in PCRs with $P$. corrugata-specific primers.
$P$. corrugata has already been shown to induce pithnecrosis symptoms on solanaceous hosts (Siverio et al., 1993; Catara et al., 1997; Sutra et al., 1997). No symptoms on courgette have been previously observed (Sutra et al., 1997). Strains in this study induced lesions whose size varied independently of the strain used, and no statistical difference was observed between the different tomato varieties tested (data not shown). No correlation between pathogenicity or virulence and the distribution of tested strains within the two phena (A and B) was observed. By applying a polyphasic approach combining numerical analysis of phenotypic data, DNA-DNA hybridization, PCR-based DNA typing methods applied to the whole genome (REPand BOX-PCR) or to selected genetic regions (16S rDNA or ITS), and 16S rDNA sequence analysis, we were able to delineate clearly two closely related, but distinct, taxa within the present $P$. corrugata species. Strains of phenon A, which contain the type strain CFBP $2431^{\mathrm{T}}$, correspond to true $P$. corrugata. According to our results, strains of phenon $\mathrm{B}$ must be assigned to a novel species, for which the name Pseudomonas mediterranea is proposed.

\section{Description of Pseudomonas mediterranea sp. nov.}

Pseudomonas mediterranea (me.di.ter.ra.ne'a. M.L. adj. mediterranea mediterranean, referring to the fact that most strains of this species were isolated in Mediterranean countries).

The description of the species is based on results presented in this study and in previous studies (Catara et al., 1997, 2000; Sutra et al., 1997). P. mediterranea is a Gram-negative, non spore-forming rod. This species have the same general characteristics as P. corrugata. Colonies on YPGA are wrinkled or smooth. Yellow to brown pigments are frequently produced. Motile by means of multiple polar flagella. It is strictly aerobic, non-fluorescent on King's B medium, oxidase-positive, does not produce levan, is not pectolytic, and reduces nitrates into nitrites. Most strains (seven out of eight tested) are arginine dihydrolase-positive after 15 days incubation, and few (two out of eight tested) produce hypersentivity on tobacco leaves. Hydrolysis of Tween 80 and gelatin is variable (seven and six positive strains out of eight tested, respectively). Acid is produced from sucrose and mannitol but not from erythritol and sorbitol. $P$. mediterranea utilizes $N$-acetylglucosamine, D- and L-alanine, 4-aminobutyrate, 5-aminovalerate, D-arabitol, L-arabinose, L-aspartate, cis-aconitate, betaine, caprate, caprylate, citrate, ethanolamine, D-fructose, fumarate, D-galactose, D-galacturonate, gluconate, D-glucosamine, D-glucose, D-glucuronate, L-glutamate, glycerol, $p$-hydroxybenzoate, DL- $\beta$ hydroxybutyrate, 2-oxoglutarate, DL-lactate, D-lyxose, L-malate, malonate, D-mannitol, D-mannose, mucate, myo-inositol, L-proline, propionate, protocatechuate, putrescine, quinate, D-ribose, D-saccharate, sucrose, L-serine, succinate, D-trehalose, trans-aconitate, trigonelline, L-tyrosine and D-xylose. In contrast, it does not hydrolyse DNA or aesculin and does not utilize 
adonitol, L-arabitol, benzoate, D-cellobiose, $m$-coumarate, dulcitol, erythritol, DL-fucose, gentisate, gentobiose, L-histidine, $m$-hydroxybenzoate, hydroxyquinoline $\beta$-glucuronide, itaconate, 5-ketogluconate, lactose, lactulose, maltitol, maltose, maltotriose, Dmelezitose, D-melibiose, 1- $O$-methyl $\alpha$-galactopyranoside, 1-O-methyl $\beta$-galactopyranoside, 1-O-methyl $\beta$-D-glucopyranoside, palatinose, phenylacetate, 3phenylpropionate, D-raffinose, L-rhamnose, D-sorbitol, L-sorbose, D-tagatose, L-tartrate, tricarballylate, L-tryptophan, D-turanose or xylitol. Utilization of the following substrates is variable: D-malate, glutarate and tryptamine. P. mediterranea utilizes histamine, 2ketogluconate and meso-tartrate, whereas $P$. corrugata does not. It uses DL-glycerate but not D-tartrate, whereas the assimilation of these two substrates is variable for $P$. corrugata. $P$. mediterranea can be clearly distinguished from $P$. corrugata by $16 \mathrm{~S}$ rDNA analysis, by means of REP- and BOX-PCR profiles (this study) and by using fingerprints generated by random-primed PCR (random amplified polymorphic DNA) (Catara et al., 2000). Type I primers (PC5/1 and $\mathrm{PC} 5 / 2)$ and type II primers (PC1/1 and $\mathrm{PCl} / 2$ ) designed by Catara et al. (2000) allow the PCR identification and detection of $P$. corrugata and $P$. mediterranea, respectively. The $\mathrm{G}+\mathrm{C}$ content of the DNA of the type strain is $60 \cdot 2 \mathrm{~mol} \%$ (thermal denaturation method). The type strain is strain CFBP $5447^{\mathrm{T}}$ (= ICMP $\left.14184^{\mathrm{T}}\right)$. P. mediterranea strains were isolated from pith necrosis on tomatoes and peppers, mainly in Italy, Spain and France.

\section{ACKNOWLEDGEMENTS}

The authors wish to thank Solange Belouin for technical assistance, and Alain Huard for designing the dendrogram of phenotypic data.

\section{REFERENCES}

Achouak, W., Christen, R., Barak, M., Martel, M. H. \& Heulin, T. (1999). Burkholderia caribensis sp. nov. exopolysaccharide-producing bacteria isolated from vertisol microaggregates in Martinique. Int $J$ Syst Bacteriol 49, 787-794.

Achouak, W., Thièry, M., Roubaud, P. \& Heulin, T. (2000). Impact of crop management on intraspecific diversity of Pseudomonas corrugata in bulk soil. FEMS Microbiol Ecol 31, 11-19.

Anzai, Y., Kim, H., Park, J.-Y., Wakabayashi, H. \& Oyaizu, H. (2000). Phylogenetic affiliation of the pseudomonads based on $16 \mathrm{~S}$ rRNA sequence. Int J Syst Evol Microbiol 50, 1563-1589.

Bennik, M. H. J., Vorstman, W., Smid, J. E. \& Gorris, M. G. L. (1998). The influence of oxygen and carbon dioxide on the growth of prevalent Enterobacteriaceae and Pseudomonas species isolated from fresh and controlled-atmosphere-stored vegetables. Food Microbiol 15, 459-469.

Berry, V. \& Gascuel, O. (1996). Interpretation of bootstrap trees: threeshold of clade selection and induced gain. Mol Biol Evol 13, 999-1011.

Catara, V., Gardan, L. \& Lopez, M. M. (1997). Phenotypic heterogeneity of Pseudomonas corrugata strains from southern Italy. J Appl Microbiol 83, 576-586.

Catara, V., Arnold, D., Cirvilleri, G. \& Vivian, A. (2000). Specific oligonucleotide primers for the rapid detection of the causal agent of tomato pith necrosis, Pseudomonas corrugata: evidence for two genomic groups. Eur J Plant Pathol 106, 753-762. de Bruijn, F. J. (1992). Use of repetitive (repetitive extragenic palindromic and enterobacterial repetitive intergenic consensus) sequences and the polymerase chain reaction to fingerprint the genomes of Rhizobium meliloti isolates and other soil bacteria. Appl Environ Microbiol 58, 2180-2187.

De Vos, P., Goor, M., Gillis, M. \& De Ley, J. (1985). Ribosomal ribonucleic acid cistron similarities of phytopathogenic Pseudomonas species. Int J Syst Bacteriol 35, 169-184.

Delwart, E. L., Shpaer, E. G., Louwagie, J., McCutcham, F. E., Grez, M., Rübsamen-Waigmann, H. \& Mullins, J. I. (1993). Genetic relationships determined by a DNA heteroduplex mobility assay: analysis of HIV-1 env genes. Science 262, 1257-1261.

Descamps, P. \& Véron, M. (1981). Une méthode de choix des caractères d'identification basée sur le théorème de Bayes et la mesure de l'information. Ann Microbiol (Paris) 132B, 157-170.

Espejo, R. T., Feijóo, C. G., Romero, J. \& Vásquez, M. (1998). PAGE analysis of the heteroduplexes formed between PCR-amplified 16S rRNA genes: estimation of sequence similarity and rDNA complexity. Microbiology 144, 1611-1617.

Feinberg, A. P. \& Vogelstein, B. (1983). A technique for radiolabelling DNA restriction endonuclease fragments to high specific activity. Annal Biochem 132, 6-13.

Fiori, M. (1992). A new bacterial disease of Chrysanthemum: a stem rot by Pseudomonas corrugata Roberts et Scarlett. Phytopathol Mediterr 31, 110-114.

Gascuel, O. (1997). BIONJ : an improved version of the NJ algorithm based on a simple model of sequence data. Mol Biol Evol 14, 685-695.

Grimont, P. A. D. (1988). Use of DNA reassociation in bacterial classification. Can J Microbiol 34, 541-546.

Guasp, C., Moore, E. R. B., Lalucat, J. \& Bennasar, A. (2000). Utility of internally transcribed $16 \mathrm{~S}-23 \mathrm{~S}$ rDNA spacer regions for the definition of Pseudomonas stutzeri genomovars and other Pseudomonas species. Int J Syst Evol Microbiol 50, 1629-1639.

Jensen, M. A., Webster, J. A. \& Straus, N. (1993). Rapid identification of bacteria on the basis of polymerase chain reaction-amplified ribosomal DNA spacer polymorphisms. Appl Environ Microbiol 59, 945-952.

Kersters, K., Ludwig, W., Vancanneyt, M., De Vos, P., Gillis, M. \& Schleifer, K. H. (1996). Recent changes in the classification of the pseudomonads: an overview. Syst Appl Microbiol 19, 465-477.

Kessler, B. \& Palleroni, N. J. (2000). Taxonomic implications of synthesis of poly- $\beta$-hydroxybutyrate and other poly- $\beta$-hydroxyalkanoates by aerobic pseudomonads. Int J Syst Evol Microbiol 50, 711-713.

Lopez, M. M., Siverio, F., Albiach, R., Garcia, F. \& Rodriguez, F. R. (1994). Characterization of Spanish isolates of Pseudomonas corrugata from tomato and pepper. Plant Pathol 43, 80-90.

Louws, F. J., Fulbright, D. W., Stephens, C. T. \& de Bruijn, F. J. (1994). Specific genomic fingerprints of phytopathogenic Xanthomonas and Pseudomonas pathovars and strains generated with repetitive sequences and PCR. Appl Environ Microbiol 60, 2286-2295.

Lukezic, F. L. (1979). Pseudomonas corrugata a pathogen of tomato, isolated from symptomless alfalfa roots. Phytopathology 69, 27-31.

Magyarosy, A. C. \& Buchanan, B. B. (1995). First report of Pseudomonas corrugata causing pith necrosis on geraniums. Phytopathology 85, 1040.

Manceau, C. \& Horvais, A. (1997). Assessment of genetic diversity among strains of Pseudomonas syringae by PCR-restriction fragment length polymorphism analysis of rRNA operons with special emphasis on P. syringae pv. tomato. Appl Environ Microbiol 63, 498-505.

Marmur, J. \& Doty, P. (1962). Determination of the base composition of deoxyribonucleic acid from its thermal denaturation temperature. J Mol Biol 5, 109-118.

Moore, E. R. B., Mau, M., Arnscheidt, A., Böttger, E. C., Hutson, R. A., Collins, M. D., Van de Peer, Y., De Wachter, R. \& Timmis, K. N. (1996). The determination and comparison of the 16S rRNA gene sequences of species of the genus Pseudomonas (sensu stricto) and estimation of the natural intrageneric relationships. Syst Appl Microbiol 19, 478-492. 
Owen, R. J. \& Lapage, S. P. (1976). The thermal denaturation of partly purified bacterial deoxyribonucleic acid and its taxonomic implications. J Appl Bacteriol 41, 335-340.

Padaga, M., Heard, G. M., Paton, J. E. \& Fleet, G. H. (2000). Microbial species associated with different sections of broccoli harvested from three regions in Australia. Int J Food Microbiol 60, 15-24.

Palleroni, N. J. (1984). Genus I Pseudomonas Migula 1894. In Bergey's Manual of Systematic Bacteriology, pp. 141-199. Edited by N. R. Krieg \& J. G. Holt. Baltimore: Williams \& Wilkins.

Paulitz, T., Zhou, C. \& Rankin, L. (1992). Selection of rhizosphere bacteria for biological control of Pythium aphanidermatum on hydroponically-grown cucumber. Biol Control 2, 226-237.

Rademaker, J. L. W., Louws, F. J., Schultz, M. H., Rossbach, U., Vauterin, L., Swings, J. \& de Bruijn, F. J. (1997). Molecular systematics of xanthomonads by rep-PCR genomic fingerprinting and computer-assisted pattern analysis. Phytopathology 87, S81.

Rademaker, J. L. W., Hoste, B., Louws, F. J., Kersters, K., Swings, J., Vauterin, L., Vauterin, P. \& de Bruijn, F. J. (2000). Comparison of AFLP and rep-PCR genomic fingerprinting with DNA-DNA homology studies: Xanthomonas as a model system. Int J Syst Evol Microbiol 50, 665-677.

Ryder, M. H. \& Borrett, M. A. (1991). Root colonization by nonfluorescent pseudomonads DS used for the control of wheat take-all. Bull SROP 14, 302-307.

Sambrook, J., Fritsch, E. F. \& Maniatis, T. A. (1989). Molecular Cloning: a Laboratory Manual, 2nd edn. Cold Spring Harbor, NY: Cold Spring Harbor Laboratory.

Scarlett, C. M., Fletcher, J. T., Roberts, P. \& Lelliott, R. A. (1978). Tomato pith necrosis caused by Pseudomonas corrugata n. sp. Ann Appl Biol 88, 105-114.

Scortichini, M. (1989). Occurence in soil and primary infections of Pseudomonas corrugata Roberts and Scarlett. J Phytopathol 125, 33-40.

Siverio, F., Cambra, M., Gorris, M. T., Corzo, J. \& Lopez, M. M. (1993). Lipopolysaccharides as determinants of serological variability in Pseudomonas corrugata. Appl Environ Microbiol 59, 1805-1812.

Siverio, F., Carbonell, E. A., Garcia, F. \& Lopez, M. M. (1996).
Characteristic of the whole cell fatty profiles of Pseudomonas corrugata. Eur J Plant Pathol 102, 519-526.

Solaiman, D. K. Y., Ashby, R. D. \& Foglia, T. A. (2000). Rapid and specific identification of medium-chain-length polyhydroxyalkanoate synthase gene by polymerase chain reaction. Appl Microbiol Biotechnol 53, 690-694.

Stackebrandt, E. \& Goebel, B. J. (1994). Taxonomic note: a place for DNA-DNA reassociation and $16 \mathrm{~S}$ rRNA sequence analysis in the present species definition in bacteriology. Int J Syst Bacteriol 44, 846-849.

Stead, D. E. (1992). Grouping of plant-pathogenic and some other Pseudomonas spp. by using cellular fatty acid profiles. Int $J$ Syst Bacteriol 42, 281-295.

Sutra, L., Siverio, F., Lopez, M. M., Hunault, G., Bollet, C. \& Gardan, L. (1997). Taxonomy of Pseudomonas strains isolated from tomato pith necrosis: emended description of Pseudomonas corrugata and proposal of three unnamed fluorescent Pseudomonas genomospecies. Int J Syst Bacteriol 47, 1020-1033.

Vancanneyt, M., Torck, U., Dewettinck, D., Vaerewijck, M. \& Kersters, K. (1996). Grouping of pseudomonads by SDS-PAGE of whole-cell proteins. Syst Appl Microbiol 19, 556-568.

Vandamme, P., Pot, B., Gillis, M., De Vos, P., Kersters, K. \& Swings, J. (1996). Polyphasic taxonomy, a consensus approach to bacterial systematics. Microbiol Rev 60, 407-438.

Van Outryve, M. F., Cerez, M. T., De Cleene, M., Swings, J., Mew, T. W. (1992). Pathogenic pseudomonads associated with sheath rot and grain discoloration of rice. Abstracts of the 8th International Conference on Plant Pathogenic Bacteria, Versailles, France. Abstract P1/A5. INRA

Vauterin, L., Rademaker, J. \& Swings, J. (2000). Synopsis on the taxonomy of the genus Xanthomonas. Phytopathology 90, 677-682.

Versalovic, J., Schneider, M., de Bruijn, F. J. \& Lupski, J. R. (1994). Genomic fingerprinting of bacteria using repetitive sequence based PCR (rep-PCR). Methods Mol Cell Biol 5, 25-40.

Wayne, L. G., Brenner, D. J., Colwell, R. R. \& 9 other authors (1987). International Committee on Systematic Bacteriology. Report of the ad hoc committee on reconciliation of approaches to bacterial systematics. Int J Syst Bacteriol 37, 463-464. 